\title{
German research bodies urged to open up more to new ideas
}

[MUNICH] An external evaluation committee has urged Germany's two main basic research organizations to stop living on past glories and to embark on reforms that will make them more responsive to modern research needs. Federal and regional governments, says the committee, should help by relaxing restrictive employment laws.

The committee was set up in 1997 by the Bund-Länder Kommission (BLK) - the body that coordinates regional and federal research policies - to assess the procedures of the Max Planck Society (MPS) and the Deutsche Forschungsgemeinschaft (DFG), Germany's university funding agency.

Ten non-German scientists and sciencepolicy experts were asked to consider whether the bodies' organizations allowed them to support the best research and respond quickly to new research areas.

The committee's report, submitted to the BLK last week, includes few surprises. The two research organizations, however, say it will provide moral support for important reforms that are already partly under way. But they stress that not all the recommendations
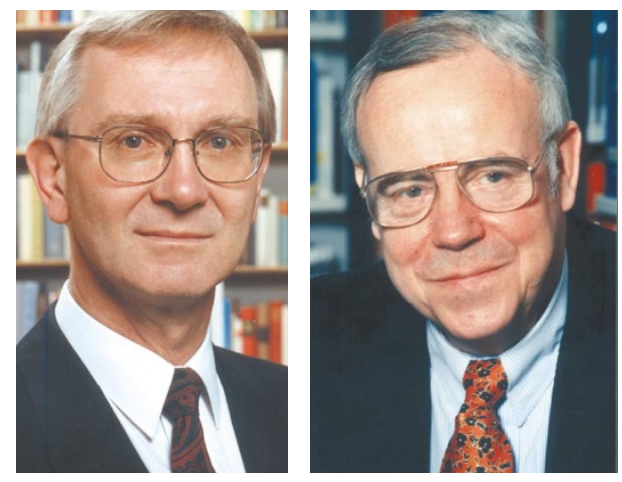

MPS's Markl, left, and DFG's Winnacker: keen to improve the lot of Germany's young researchers.

are likely to be implemented; only those compatible with their fundamental principles in particular, their political autonomy - will see the light of day.

The report highlights many well-known problems in German science, including inadequate academic career opportunities for young researchers, restrictive employment laws that prevent organizations from offering competitive salaries to top

\section{US labs braced for anti-spying legislation}

[WASHINGTON] The US Congress is expected to pass legislation in the near future restricting foreign scientists' visits to nuclear-weapons laboratories. The move is a response to accusations of spying by China, which reached their peak last week with the release of a report by a Congressional committee chaired by Christopher Cox (Republican, California).

Scientific societies are working to influence the legislation, which is certain to be passed in response to the scandal. Despite public expectations of a clampdown on partnerships with foreign scientists, laboratory officials and the societies are confident that the legislation will be framed so as to allow partnerships to continue.

Critics of the Clinton administration in Congress are talking about clamping down on foreign visits to the laboratories, but in practice their room for manoeuvre is constrained by the need to keep the weapons laboratories scientifically competitive.

"The Congress is attempting a legislative fix to a problem that isn't amenable to a legislative solution," says an official at one scientific society. "A large number of people, including foreign scientists, come into occasional contact with people who do the classified work. There is no way to stop that without harming the US nuclear weapons programme."

Defence bills passed by the Senate, and expected to be passed by the House of Representatives after the recess, include special provisions on laboratory security. The laws will impose conditions on visits by scientists from so-called 'sensitive countries' to the three nuclear weapons laboratories: Lawrence Livermore in California, and Sandia and Los Alamos in New Mexico.

A proposal from Jim Ryun (Republican, Kansas) would drastically curtail foreign visits to weapons laboratories. But a more pragmatic package proposed by Norm Dicks (Democrat, Washington), the senior Democrat on the investigative committee, and backed by Cox, is likely to form the basis of the final legislation, observers say.

Under this proposal, visitors to the laboratories from the sensitive countries, which include Russia, China and India, would face a 60 -day moratorium until new vetting procedures have been implemented.

The parts of non-weapons laboratories which these scientists normally visit will not be affected. But some of these, including Brookhaven, have already stepped up their vetting procedures in response to the Chinese spying scandal.

Colin Macilwain researchers, and working conditions that hamper the progress of women.

A general problem in both universities and MPS institutes is the time and effort needed to establish a research career. The report says that Habilitation - the German postdoctoral teaching and research qualification required by most universities for faculty membership — should be abandoned, because it delays careers unnecessarily. More funding, it says, should be available for junior independent research groups.

Such comments are music to the ears of Ernst-Ludwig Winnacker and Hubert Markl, respective presidents of the DFG and MPS. Both are champions of young scientists, and both have created programmes to support independent young-scientist research groups in the past few years.

But other comments in the report are more difficult for them to swallow. The DFG was criticized for its "tendency towards a conservative approach" to science funding. The report says the agency should "not only respond to long-term developments, but should actively influence them", acknowledging the DFG's success in funding mainstream research, but criticizing its record in funding interdisciplinary research and work in new areas.

The report also says that the DFG's peerreview system needs to be more responsive to new ideas. In response, Winnacker says he is aware that the DFG needs to break out of its self-reproducing peer-review system, and says mechanisms for this are in place.

The DFG's core of about 500 referees is elected by German academics from the nominations of the country's scientific societies, and organized into 37 committees (Fachausschüsse) divided according to discipline. This core, which is dominated by older, more established scientists, is supplemented by three times as many outside referees.

These outside referees may be called upon more often in the future, says Winnacker, saying that "in the past few years we have managed to reduce the average age of the members of our selection committees by ten years". But he adds that there are limits to how far DFG staff can go in selecting referees.

The DFG prides itself on being an organization run by and for researchers. Many scientists believe that most of its decisions should only be made by representatives elected by the community. "We will need to discuss the issue in depth," says Winnacker.

Winnacker is also uncomfortable with the evaluation committee's call for the DFG to develop 'strategic' research programmes, 
making it more than an organization that simply reacts to ideas from the community. He argues that a 'top-down' role for the DFG may be incompatible with its autonomy, a characteristic much acclaimed in the report.

Although the DFG does not oppose the principle of creating new programmes, Winnacker says "it is important that these are selected either by the research community itself, or in an interplay between DFG staff and the research community".

The report recognizes that the work of the DFG has grown enormously over the past decade, increasing the burden on DFG staff and their referees, and it recommends that the number of elected referees be increased by a quarter.

This suggestion, which is already being implemented by the DFG, is particularly welcome, says Klaus-Peter Hoffmann, professor of zoology and neurobiology at the University of Bochum, and a biology referee for the DFG for 25 years. Hoffmann receives 300 grants to review every year, and says the pressure crushes creativity. "When overburdened, one tends to shy away from risk, and this is one reason we have tended to avoid entering new territory," he says.

The MPS, while praised for the quality of its research, comes in for criticism for being "isolated from the university system" and for sticking too closely to the "Harnack princi- ple' on which it is based. This principle causes research to be concentrated in institutes headed by directors selected for their scientific stature rather than their research area.

Directors are appointed for life, receive generous support for their research and have complete freedom to choose the direction of their research. But the report says that this could hamstring the society by tying up too many resources in a single person for decades.

The report also calls for "International Max Planck Research Schools" to be created at universities to allow graduates to benefit from the expertise of local Max Planck institutes. It says that time-limited Max Planck research units should be created at universities. Both measures, it says, would help bring the MPS and universities into closer contact.

Although Markl supports cooperation with universities, he questions whether the committee, who did not review university research, was aware of the close cooperation that already exists in some places. He points out, for example, that "ten per cent of MPS directors now have university chairs".

But Axel Ullrich, a director of the Max Planck Institute for Biochemistry, near Munich, says that the current links are patchy and dependent on personal contacts. Ullrich has not been made a university professor, because most of his career was spent in the
United States, "so I was not established in academic circles in Munich". He welcomes closer contact between the two institutions.

Markl is in favour of international research schools. But he is "not yet sure" of the value of creating Max Planck groups in universities, as this moves away from the Harnack principle and, he says, could stretch resources too thinly.

Markl says that reforms will have to be paid for out of the five per cent annual budget increase promised by the German gov-

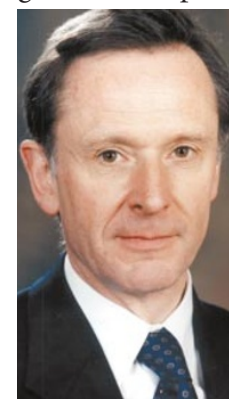

Brook: backs 'topdown' guidance. ernment for the next few years. "My first priority is to complete our plans for building up MPS activities in East Germany," he says. Future reforms will depend on whether the MPS can afford them.

Richard Brook, head of Britain's Engineering and Physical Sciences Research Council and chair of the committee, says that the MPS and DFG need to become more accessible to young scientists and women - "we were shocked to realize that only three per cent of MPS directors are women". Brook also says that the DFG should not necessarily be afraid of giving 'top-down' guidance. Alison Abbott\& QuirinSchiermeier

\section{Proceed with caution, says UK report on ethics of GM foods}

[LONDON] Last month's decision by the British government to strengthen the monitoring of genetically modified (GM) foods but resist calls for a moratorium on their commercial planting has been implicitly endorsed by the main UK bioethics advisory body (see Nature 399, 287; 1999).

In a report published last week, the Nuffield Council on Bioethics says that there are many aspects of the development and introduction of GM foods that warrant firm government action (see page 405 in this issue). These range from steps to limit the breadth of patent claims to what it describes as a "moral imperative" to develop GM staple foods for the Third World.

But the report dismisses opposition to GM crops based either on broad claims about their 'unnaturalness' or on their potential for misuse. The genetic modification of crop plants, it says, "does not differ to such an extent from conventional plant breeding or other human interventions with the natural world as to make the process morally objectionable in itself".

The overall message has been welcomed by the agrobiotech industry and the government. Jack Cunningham, the cabinet minister responsible for the government initiatives, said the report was "independent backing for the government's approach”.
The response has been cooler from environmentalist, Third World and religious groups, upset that the report's admittedly utilitarian stance does not pay closer heed to the ways that GM technology has been and is likely to be - used.

The report, Genetically Modifed Crops: The Ethical and Social Issues, was drawn up by a working party chaired by Alan Ryan, professor of philosophy at the University of Oxford. It outlines three areas in which, it claims, moral considerations are relevant: general welfare, people's rights (for example, to freedom of choice as consumers) and the principle of justice - the fair sharing of burdens and benefits.

From this perspective, while endorsing the patenting of genetic sequences, it urges national and international patent bodies to discourage patents "which allow extensive control over a single crop species," and to draw up new guidelines for doing so.

The report also strongly endorses the use of GM crops in the Third World, arguing that the British government should allocate a "substantial amount" of its increased aid budget to research and development on GM food staples grown in developing countries.

But it also urges careful attention to the potential environmental impacts of GM crops, as well as to ensuring that farmers in these countries are given a choice between GM crops and traditional varieties.

By sticking to its three ethical principles, the working group rejects the demands of some critics to take a broader ethical stance. "It is the deleterious consequences of our farming techniques to our environment and public health, not their 'unnatural' character that should preoccupy us," the working group says.

Thus, although supporting in principle the labelling of GM foods, it opposes labelling as "not necessary or practical" for foods produced by a GM process where no difference can be detected.

The Third World group Christian Aid, which recently issued a report arguing that GM crops were unnecessary for problems that could be resolved by better food distribution (see Nature 399, 99; 1999), claimed that the council was "out of touch" with the real causes of hunger.

Donald Bruce, who heads a project on GM foods for the Church of Scotland, says that although he agrees with much of the working party's conclusions, the report's dismissal of the 'unnaturalist' position is "a dogma rather than a serious argument".

But Ryan defends the working party, saying that the report "is intended to be read in a highly pluralistic society”. David Dickson 